\title{
A new species of the genus Pseudopoda (Aranei: Sparassidae) from Yunnan Province, China
}

\author{
Новый вид пауков рода Pseudopoda (Aranei: Sparassidae) \\ из провинции Юньнань, Китай
}

\author{
Cai-Kun Sun ${ }^{1} \&$ Feng Zhang ${ }^{2}$ \\ Цай-Кун Сун ${ }^{1}$, Фень ЖКань \\ College of Life Sciences, Hebei University, Baoding, Hebei 071002, China. \\ E-mail: 1'suncaikun1982@126.com, 2dudu06042001@163.com (corresponding author) \\ KEY WORDS: taxonomy, Sparassidae, Pseudopoda, new species. \\ КЛЮЧЕВЫЕ СЛОВА: таксономия, Sparassidae, Pseudopoda, новый вид.
}

ABSTRACT. Pseudopoda kunmingensis sp.n., from Yunnan, China, is described and illustrated.

РЕЗЮМЕ. Приведено иллюстрированное описание нового вида Pseudopoda kunmingensis sp.n. из Юньнаня (Китай).

\section{Introduction}

The spider family Sparassidae Bertkau, 1872, currently contains 83 genera and 1094 species worldwide [Platnick, 2011]. At present 99 species of 11 genera are reported from China [Song et al., 1999; Li \& Wang, 2011; Platnick, 2011].

The genus Pseudopoda was established by Jäger in 2000, and Sarotes promptus O. Pickard-Cambridge, 1885 , was designated as the type species. Nine known Heteropoda species were transferred to this new genus [Jäger, 2000]. All species in the genus can be recognized by the membranous conductor, broadened and flattened embolus, lengthened tegulum in the male palpal organ, and the presence of lateral lobes rising distinctly beyond epigastric furrow posteriad in the female epigynum. At present, thirty-six species are known from China [Li \& Wang, 2011; Platnick, 2011]; among them, twentythree species are known from Yunnan Province, and Yunnan is considered as the center of the distribution range of the genus Pseudopoda [Jäger \& Vedel, 2007; Jäger, 2008; Yang et al., 2009].

While examining spider specimens collected in 2004 from Yunnan, China, a new Pseudopoda species was recognized, and it is described below: Pseudopoda kunmingensis sp.n.

\section{Materials and Methods}

Carapace length was measured from the anterior margin to the rear margin of the carapace medially.
Total length is the sum of carapace and abdomen length regardless of the petiolus and abdominal overlap. Eye sizes were measured as the maximum diameter in dorsal or frontal view. The measurements of legs are shown as total length (femur + patella + tibia + metatarsus + tarsus). The chaetotaxy is given in the following formula: femur I-III 3230 (3 pro-lateral, 2 dorsal, 3 retro-lateral and no ventral spines). All specimens were preserved in $75 \%$ ethyl alcohol and examined, drawn and measured under a Tech XTL-II stereomicroscope equipped with an Abbe drawing device. Epigyne were removed and cleared in 10\% warm solution of potassium hydroxide $(\mathrm{KOH})$, and transferred to alcohol for drawing. All measurements given are in millimeters.

The following abbreviations are used: ALE - anterior lateral eye; AME — anterior median eye; AMEALE - distance between AME and ALE; AMEAME - distance between AMEs; ALE - PLE - distance between AME and PLE; PLE - posterior lateral eye; PME - posterior median eye; PME-PLE - distance between PME and PLE; PME-PME - distance between PMEs; MOA — median ocular area; RTA retrolateral tibial apophysis.

Type specimens are deposited in the Museum of Hebei University (MHBU), Baoding, China.

\section{Taxonomy \\ Pseudopoda kunmingensis sp.n. Figs 1-7.}

TYPE MATERIAL. Male holotype, Yunnan Province, Kunming City, Xishan National Forest Park (al. 1967m, $24^{\circ} 582$ N, $102^{\circ} 372$

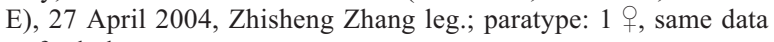
as for holotype.

ETYMOLOGY. The specific name refers to the type locality; adjective.

DIAGNOSIS. This new species is similar to $P$. daliensis Jäger \& Vedel [Jäger \& Vedel, 2007: 23, figs 


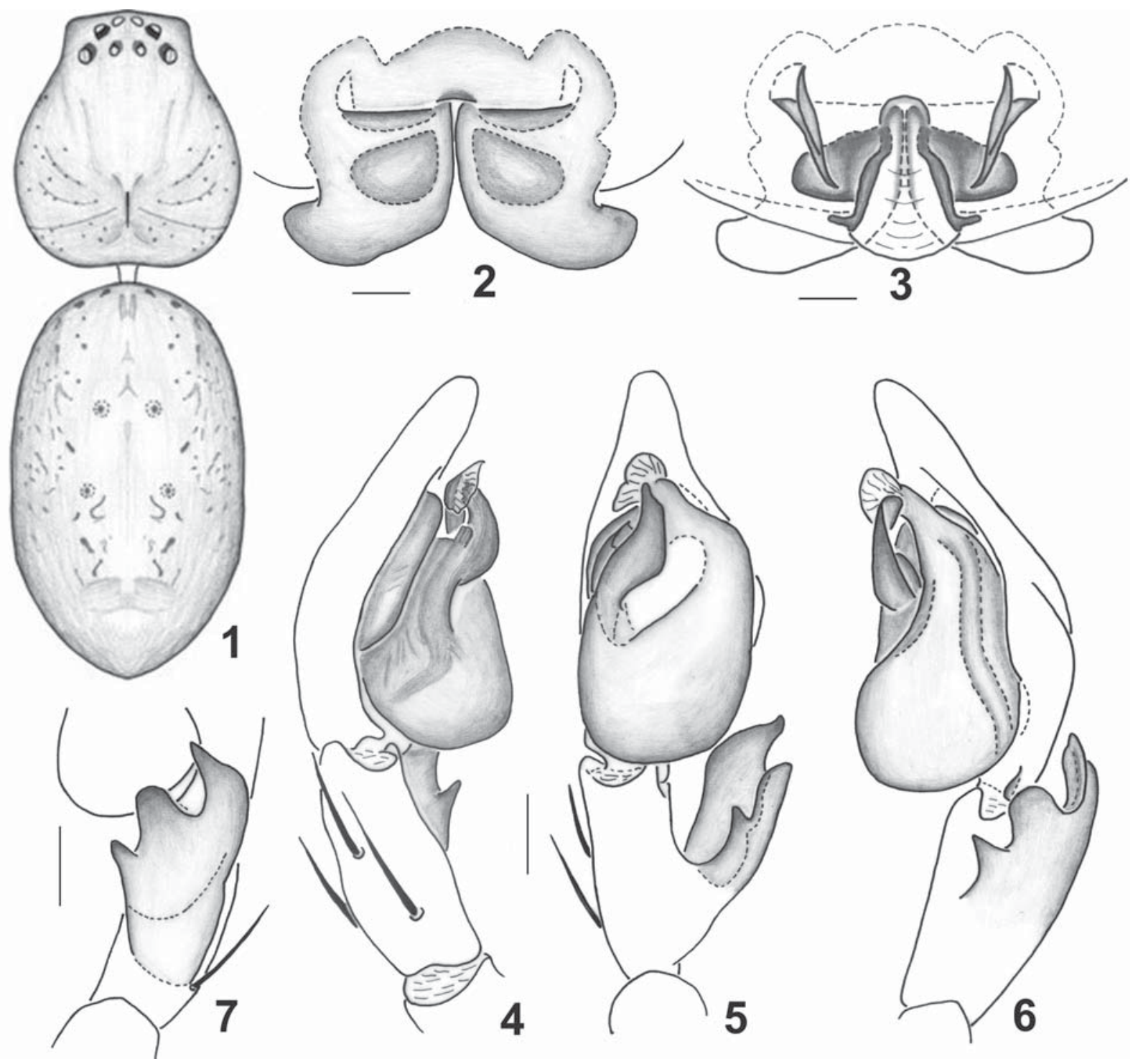

Figs 1-7. Pseudopoda kunmingensis sp.n., male holotype (4-7) and female paratype (1-3): 1 - female body, dorsal view; 2 epigyne, ventral view; 3 - vulva, dorsal view; 4 - male left palp, prolateral view; 5 - same, ventral view; 6 - same, retrolateral view; 7 - male left palpal tibia, showing RTA, retrolatero-dorsal view. Scale bars: $1-1 \mathrm{~mm} ; 2-7-0.2 \mathrm{~mm}$.

Рис. 1-7. Pseudopoda kunmingensis sp.n., голотип самец (4-7) и паратип самка (1-3): 1 - тело самки, сверху; 2 - эпигина, вентрально; 3 - вульва, дорзально; 4-6 - левая пальпа самца, пролатерально, вентрально и ретролатерально; 7 - голень пальпы, ретро-дорзально, показан отросток. Масштаб: $1-1$ мм; 2-7 - 0,2 мм.

79-90, 137], but can be distinguished from the latter by: (1) the rectangular tegulum, embolus arising from 9-o'clock-position on tegulum, and its tip pointing dorsally (Fig. 5); (2) ventral part of RTA, blunt with one triangular projection in the retrolateral (Figs 5, 6); (3) the entirely horizontal anterior margins of lateral lobes, and not bent posteriorly at their lateral ends (Fig. 2); (4) distance of the posterior margins of lateral lobes wider than $P$. daliensis (Fig. 3). (5) the longer fertilization ducts (Fig. 3).

DESCRIPTION. Male (holotype): Total length 7.65: carapace 3.57 long, 3.26 wide; opisthosoma 4.08 long, 2.55 wide. Carapace yellowish-brown. Cervical groove and radial furrow obvious. Fovea long, longitudinal, dark brown. Eyes surrounded by black rings. Both eye rows slightly recurved. Eye diameters and interdistances: AME 0.18, ALE 0.25, PME 0.20, PLE 0.30; AMEAME 0.18, AME-ALE 0.08, PME-PME 0.30, PMEPLE 0.30. MOA 0.65 long, anterior width 0.50 , posterior width 0.65 . Clypeus height 0.25 . Chelicerae yellow with 3 teeth on promargin, 4 teeth on retromargin, and some denticles between them. Labium, endites yellow. Sternum yellow with dark brown setae. Legs yellow and spinose. Femora with dark spots. Leg measurements: I $17.14(4.59,1.73,4.90,4.28,1.63)$, II $17.75(5.0,1.73,4.90,4.49,1.63)$, III 14.18 (4.18, 
$1.33,3.88,3.57,1.22)$, IV 16.10 (4.59, 1.53, 3.98, $4.49,1.43)$. Leg formula: 2143 . Leg spination: palp 1310, 1010, 2121; femur I 3230, II-III 3330, IV 3210; patellae I-III 0010, IV 0000; tibiae I-II 2128, III-IV 2126; metatarsi I-II 2024, III 3034, IV 3036. Opisthosoma oval, dorsum dark brown. Venter light brown, with some brown spots.

Male palp (Figs 4-7). Embolus arising from 9o'clock-position on tegulum, its tip pointing dorsally; conductor arising from 12-o'clock-position from tegulum; sperm duct running along retrolateral tegular margin in retrolateral view (invisible in ventral view); RTA arising basally from tibia, ventral part blunt with one triangular projection in the retrolateral.

Female (paratype): Total length 10.71: Carapace 4.39 long, 3.98 wide; opisthosoma 6.32 long, 4.18 wide. Eye diameters and interdistances: AME 0.20, ALE 0.30, PME 0.23, PLE 0.30; AME-AME 0.20, AME-ALE 0.08, PME-PME 0.35, PME-PLE 0.38. MOA 0.75 long, anterior width 0.50 , posterior width 0.75 . Clypeus height 0.33 . Chelicerae yellow with 3 teeth on promargin, 4 teeth on retromargin, and some denticles between them. Labium, endites yellow. Sternum yellow with dark brown setae. Legs yellow and spinose. Femora with dark spots. Leg measurements: I 16.22 (4.69, 1.84, 4.28, 3.88, 1.53), II 17.65 (5.1, 1.83, $4.69,3.98,2.04)$, III 13.97 (4.28, 1.73, 3.57, 3.16, 1.22), IV $15.71(4.90,1.63,3.77,4.08,1.32)$. Leg formula: 2143. Leg spination: palp 131, 101, 2121, 1021; femora I-II 3230, III 3330, IV 3310; patellae IIII 0010, IV 0000; tibiae I-II 2128, III-IV 2126; metatarsi I-II 2024, III 3024, IV 3036. Carapace light brown. Labium light yellow. Sternum light brown, with some brown setae. Opisthosoma oval, dorsum yellowishbrown, musle impression obvious. Venter light brown with irregular brown patterns.
Epigynum (Figs 2-3). Epigynal field wider than long, anterior margin of lateral lobes almost horizontal; without wrinkles in anterior half of epigyne. Posterior part of lateral lobes with arc bending, smooth.

DISTRIBUTION. Known only from the type locality.

ACKNOWLEDGEMENTS. We are grateful to Dr. Zhisheng Zhang for collecting the specimens. We are particularly grateful to Drs Yuri M. Marusik and Peter Jäger for reviewing the manuscript. This work was supported by the National Natural Science Foundation of China (No. $31071885,31093430,30970325)$ and in part by the Doctoral Program Foundation of Institutions of Higher Education of China (No. 20091301120005) to Prof. Feng Zhang.

\section{References}

Jäger P. 2000. Two new heteropodine genera from southern continental Asia (Araneae: Sparassidae) // Acta Arachnologica. Vol.49. P.61-71.

Jäger P. 2008. Sparassidae from China 5. Pseudopoda songi sp. n. from Yunnan Province (Arachnida, Araneae, Sparassidae, Heteropodinae) // Senckenbergiana biologica. Vol.88. P.45-48.

Jäger P., Vedel V. 2007. Sparassidae of China 4. The genus Pseudopoda (Araneae: Sparassidae) in Yunnan Province // Zootaxa. Vol.1623. P.1-38.

Li S.Q., Wang X.P. 2011. Endemic spiders in China. Online at: http://www.ChineseSpecies.com. (Accessed 25 April 2011)

Platnick N.I. 2011. The World Spider Catalog, version 11.5. American Museum of Natural History, online at http://research.amnh. org/entomology/spiders/catalog/index.html. (Accessed 25 April 2011)

Song D.X., Zhu M.S., Chen J. 1999. The Spiders of China. Shijiazhuang: Hebei Science and Technology Publishing House. 640 p.

Yang Z.Z., Chen Y.Q., Chen Y.L., Zhang Y.G. 2009. Two new species of the genus Pseudopoda from Yunnan, China (Araneae: Sparassidae) // Acta Arachnologica Sinica. Vol.18. P.18-22.

Responsible editor Yu.M. Marusik 